\title{
UDC101.1
}

\section{NIZAMI AND THE SILENT BODY OF POETRY}

\author{
Paul Ballanfat \\ Galatasaray Universitesi Istanbul \\ NIZAMI POEZIYASININ SOSSIZZ ŞAHIDİ \\ Pol Balanfat
}

Xülasə. Müəllifin özünün də qeyd etdiyi kimi, N. Gəncəvinin poetik ədəbi irsinə həsr olunmuş çox sayda tədqiqat əsərləri yazılmışdır. Lakin o, (müəllif) şairin qeyd olunacaq yubileyi münasibətilə yaranmış imkandan istifadə edərək və N. Gəncəvi ədəbi irsinə müraciətdə yüksək erudisiya tələbinə iddialı olmadan, sadəcə şairin məşhur, ən çox tanınan əsərlərinə deyil, məhz "Divan"ından topladığı nadir, az işlənən deyim, ifadə və beytləri üzərində dayanmağa cəhd etmişdir.

Bu şeirlərin (əsasən də qəzəllərin) məhz şairin özünə aid olması məsələsinə toxunan müəllif qeyd edir ki, şairin spesifik qəzəlləri, sevgi etirafi ilə dolu məhəbbət şeirləri yalnız onun özünə aid olub, öz imzası ilə də yazılıb. Bu xüsusda müəllif şeiriyyətlə Orta Şərq adətini yada salaraq qeyd edir ki, şairlər öz ad və ya təxəllüslərini şeirin (qəzəlin) sonunda imza kimi verməklə, sanki son nəfəsdə, hər şeyi deyib qurtardıqdan sonara - ölüm öncəsi öz sənət əsərlərinə möhür vurmuş olurlar.

Müəllif N. Gəncəvinin yaradıcılıq ustalığından söz açaraq, onun qızılgül haqqında şeirini nümunə kimi missal çəkir. Belə ki, bu şeirdə şair sanki qızılgül haqqında özü danışmır, öz susqunluğu ilə gülə imkan verir ki, öz keyfiyyətləri, gözəlliyi barədə, sanki bunları şair deyirmiş kimi söz açsın. Şairin varlığı seirdə hiss olunmur, burada ənənəvi filosof və mütəfəkkirlərin (Platon, Rumi və b.) fikirləri və deyimləri yoxdur.

Açar sözlər: poeziya, Nizami Gəncəvi, "Divan”, səssiz şahid, mahiyyət

\section{НИЗАМИ И БЕЗМОЛВНЫЙ СВИДЕТЕЛЬ ПОЭЗИИ. Поль Баланфат}

Резюме. Поэтическому искусству Низами Гянджеви посвящено огромное множество исследований, пишет автор в статье. И он, пользуясь возможностью ввиду празднования Низами в Азербайджане (хотя и не претендует на то, чтобы состязаться эрудицией, требуемой для обращения к этому наследию поэтических памятников), делает попытку остановиться на редких высказываниях поэта, собранных им из «Дивана», нежели из более известных, признанных его произведений. Затрагивая вопрос о принадлежности стихов поэта, в особенности статуса элегий (газелей), он упоминает заявление самого поэта о том, что специфически утвержденные элегии (газели), любовные стихи с признанием собственной любви принадлежат ему или стоят за его подписью. В этой связи автор упоминает о Средне Восточной традиции представления имени автора и его подписи в конце произведения, словно перед самой смертью, на последнем издыхании, после того как уже все сказано.

Раскрывая мастерство и творческие приемы поэта, автор приводит в качестве примера его стих о розе. Он не говорит о ней сам, позволяет своим молчанием высказаться ей самой, выявлять качества, которые поэт хотел бы показать. Его присутствие рядом нигде не отмечено, нет традиционного описания предмета, так как это убило бы его. И он, как безмолвный свидетель явления, своё присутствие и местонахождение держит в тайне, обещая объявиться 
в конце стиха, но уже преобразившись в соловья. Низами не дарит стих розе, позволяет ей самой его творить.

Исходя из других редких изречений поэта, автор обращает внимание на те, где говорится поэтом, что он оставляет знаки, свои следы, таинства - скрытые в самих буквах его языка.

Поэзия, делает заключение автор, представляет единство возможного и невозможного, возникновение чего-либо и его исчезновение. В этом смысле она бессмысленна. Свои доводы автор подкрепляет выдержками и изречениями философов и мыслителей прошлого (Платона, Руми и др.) и строками из Корана.

Ключевые слова: поэзия, Низами Гянджеви, «Диван», безмолвный свидетель, сущность, подпись, мастерство.

\section{İntroduction}

Nizami Ganjavi, born and died in the city of Ganja in Azerbaijan, is the author of many works essential to Persian speaking literature. A lot of studies have been dedicated to his poetical art and I won't pretend I could compete with so much erudition that is required anyway when dealing with these poetical monuments that constitute the legacy of our becoming. The decision of Azerbaijan to celebrate Nizami gives me an opportunity to try to focus on some of his expressions that I picked rather from his Diwan than from his more celebrated other works. When reading the Diwan my attention was stopped by some of his rare sayings dealing with what could mean speaking or rather speaking poetically.

In one of his elegy Nizami writes:

$$
\text { ياهلز غيماظن رب رثا دوب · دريكن رد وت جيه منوسفا يا ناج }
$$

Nizami qualifies his own poetry in this small verse. He doesn't make a general statement about poetry, but he defines the status, or rather describes, of a formal part, the elegies ( ghazal), of the poetry that he declares belonging to him, or at least being recorded with his signature. Strange statement, if we dare claiming the right to question it, which is a claim that silently allows any writing as Plato had at least once mentioned. When poetry is divided into types, guises, ways, forms, it is instantly constituted as a formal institution that escapes necessarily the grasp of the one who claims to be its author and thus to own it. The institution of poetry both records the ownership of the author and challenges it by removing this ownership to the authority that recognizes and declares this belonging. The instituted poetry, the recognized poetry belongs and doesn't belong to its author. The author is somehow also instituted as the author it is through the institution of some kind of copyright that separates him from himself. The poetry is included within a general corpus of common literary legacy that belongs to all those who are recognized the right to read it while it institutes the authorship of the author that is at the same time included within a right of paternity, some kind of participation, and forced by the law of instituted poetry to let go and abandon his work to those who are given the right to read and, like me, dare to give the comments they wish to. However Nizami states that these specific instituted poems, the elegies, love-poems, poems confessing his own love, his very personal love, belong to him. His signature comes as a claim of ownership, or rather as a kind of taking back what poetry itself forces him to abandon to the reader. His signature is an owning back, a reclaiming, always late compared to the poem itself. The poem pours out of what is not there, of some enigma, that comes back, that is always late compared to his own utterance. The author of the poem comes after his poem. The institution marked also this delay that constitutes the poet. It is as if the poet would always be the late witness of what happened in which he was already involved although without a name. His name comes necessarily after the po$\mathrm{em}$, and the habit in Middle-Eastern poetry is precisely to sign the poem at the edge of its ending, when it is about to stop speaking, at the edge of death. The poet's name happens just before his speaking dies, in agony, like a last breath. The signature of the poet stands there as the last witness 
of the poem that happened to him while he didn't have a name yet but was waiting for his name to come as the sign pointing to himself. He is the last witness surviving his own dying speaking where he was nowhere to be found, serving his own non-appearing. Not that he disappears in his speaking but rather that he didn't yet appear. This strange speaking, and maybe any speaking, would be

the process out of which our invisibility would come through and stand all at once in the stature of the signing poet witnessing his own becoming the poet he is. Claiming back the ownership of the author, not any ownership but the ownership that is included in paternity mixing both natural bringing to existence and lawful property, appears to be the very process of this poetical art that designates the poet as the last witness of any speaking. Adorno had once proclaimed that writing poetry after Auschwitz is barbarian. However it might well be that poetry would be

the only testimony possible, the only witnessing possible, the necessary witnessing of any ending speech. The signature of the poem happening with the sudden flowing of the poet as the last witness would be the secret date printing the absence, the total oblivion, the archive, with the legacy of poetry.

The poet is silent when he is uttering the poem, as says the verse :

وك لزغ يوك يماظن و يماظن شوماخ · اى بر نآ لبلب شوماخ و لخ ايوگ نيب

The speaking poet is nowhere to be found since he is silent though he is speaking indeed. The verse could refer to this famous Koranic verse that says : "And thou threw not when thou threw but Allah threw » (Koran, 8:17), translating it poetically and drawing its consequences. The poetizing poet is nowhere to be found when he is signing with his proper noun the act of poetizing. We could immediately jump to the easy answer provided by the tradition of interpreting such addresses. We would then solve the question by saying that he is in the nowhere-place, na-kuja-abad. However, Nizami doesn't mention such a place but simply asks the question. The nowhere is not somewhere that could even be qualified as being no-where, or even the where there is no where. The nowhere is the interrogation asking where. It is thus both a question and a promise. It states that he is nowhere to be found at the time when it is asked where he is. The question both states the absence and the promise of a coming to presence. Nizami addresses himself the question about where he is to be found, and this question promises he will be found somewhere. Nizami is the one who addresses himself the question asking where he is to be found, promising himself with his question that he might be found somewhere out of his poetizing his elegy. The promise is also included in the assonances used in the verse. The words $k u$... guy jump above the verse to its end when they are differed with the sounds gul guya. The poetising poet for the beginning of the verse echoes to the speaking rose of the end of the verse while repetition of the word kamush, silent, transforms the poet signing the poem, Nizami into the nightingale that comes to be standing somewhere according to the speaking rose. The silence of the signing poet leaves the place to the speaking rose that allows through this silence the metamorphosis of the silent poet into the nightingale who listens to the speaking rose. The transformation is what the silence of the poet listening to his poem produces. It is what brings the silent poet to the promised place that brings him along with the rose of his love. Nizami is there and not here and the rose remains the rose of no-one, die Niemandsrose, as Paul Celan calls her. His silence gives speaking to the rose, offers the poem not as a product manufactured to be given as a ready made opus, but as the eventuality of the poem. The rose doesn't receive the poem from a poet who would therefore exhibit his skill in front of the poem. If it were so, the rose would be the poet pretending to honor the rose. He would be himself the qualities he sees in the rose and therefore he would steal from the rose what he pretends to find in her so that he can write a poem. The rose would be annihilated within its affirmation in the poem. The poem would thus be a perverse shift where the affirmation of the beauty of the rose would be achieved in its destruction as a standing rose. So Nizami doesn't offer a poem to the rose but offers her poetizing itself. She is both the poem and the poet, or rather the poetizing poem in the place of the poetizing poet. The love-poem is not anymore the celebration of the beauty by the poet, but the selfpresentation, the revelation of the beauty itself in its self-poetizing. The poem doesn't celebrate 
beauty, it pours out of beauty. Beauty as such poetizes whenever the poet stands in silence, precisely where he is not to be found. Renouncing to poetizing under his name, keeping his name silent, keeping the silence of the name as the very property of the proper name, leaves the poem to whom it is addressed. The poem is still addressed to the rose, but love consists precisely to leave the rose pronouncing its own address. This shift in the essence of art where art consists not anymore in producing a work of art requiring a skill to produce, a technique, but consists in abandoning speaking to whom it addresses through silence, announces the shift that Rumi will later on notice in his famous story about the art competition between the Greeks and the Chinese, where the copy surpasses the original. There too art consists not in creating a work of art through mastering a technique but to renounce creating, to give up technique so as to shift the essence of art which consists in letting appear from oneself what has to appear. Suspending technique leaves room to a way of appearing that is always dissimulated, hidden by the skill of technique. It opens the eventuality of apparition or revelation, didar, by which the poet or the artist is not anymore the creator or the producer of art but the witness of the eventuality of appearing. The poet therefore is here the silent witness, the nightingale that remains silent, the nightingale that has renounced to its singing drive. A strange nightingale indeed is the poetic nightingale. When letting the poem pour out of its address, it renounces both its proper quality, singing, and thus the way it appears and stand in being, and its proper name. He has no quality and not even a name to which it could respond. But the rose is the speaking poet that doesn't sign the poem. The rose is itself transformed by the transformation of the poet. The non-poet rose is poetizing while the poet is renouncing to write a poem. This shift is an inner switch between the essence (dhat/öz) and the qualities, between unity (ahadiyyat) and unity (wahidiyyat). The poet would usually be the principle of the poem, the agent of poetizing by which, through speaking, he covers and reveals the essence through the quality of the rose. He would witness the beauty he projects on the essence according to his own prevision of his own sight, and thus see nothing else than himself in his own state. This switch revolves around this structure. He lets the essence showing itself out of itself standing as the principle of the poem so as to be the essence of the vision that is constituted by the poem pouring out of the rose. While the creating plot would create his rose, signing it with his own proper name, Nizami is engendered by the rose that is given to speak the poem that the poet has kept in his own silence. Poetry is the silent switch of the addresses that shifts the essence to the qualities, that shifts unity through the timing of silent speaking.

Out of this first warning, Nizami announces and promises that these poems of love that are printed with his signature carry or rather include traces. They do not include or present truths, knowledges, in the guise poetry. They precisely don't obey to the injunction of Socrates in Plato's Republic who was tolerating, with a huge declared regret, the poets providing that they would just produce allegories, that is the necessary anesthetization of the truths that philosophy has the exclusive responsibility to produce. Poems are Nizami's when they don't contain truths but traces. Strange statement that says « the love-poems of Nizami are full of traces ». Traces are precisely not something that can be contained within something. They stand on the surface, like the foam on the surface of earth, or like dust on the surface of earth, two classical images of Middle-Eastern poetry. Indeed, the foam on the surface of the sea or the dust over earth can cover completely the deepness of the sea and the earth, so that they can seem as if they would be contained or, at least, like they would occupy and saturate them. The traces of poetry should be abundant enough to make disappear the deepness of the sea and the earth, the deepness of any speech pretending to be the truth and any knowledge presenting itself as knowledge. Nizami's poems pretend to accumulate so many traces that these traces would be poetry itself. Not a poetry of a wise sentences, not a petty that could be translated into a knowledge and that would give lessons, but a poetry of surface, a poetry of appearing and vanishing traces. A trace is both what is remembered, the material of remembrance itself, or more briefly said memory, and what is always on the edge of being forgotten and erased. It obeys to the grammar of archiving which is always constituted by the double impulse of 
keeping all the traces and wishing to erase all the traces. The poems of Nizami, are the inner double compulsion of remembering and forgetting, the compulsion of accumulating traces and erasing all the traces, the double movement of bringing to appearing and pushing to disappearing, some kind of a fort/da that Freud had brought to our witnessing in Beyond the Principle of Pleasure.

\section{Main part}

Full of traces is the page on which Nizami writes his poetry, covering his own silence. Remaining silent, preserving the poem within the silence of its signature, is what allows the poem to appear in its absolute simplicity. The silence of the signature is the silence of writing. Nizami mentions that he is writing. He is not just saying. And when he says he is saying love-poems as above he mentions that he is silent. His speaking is a silent speaking. Writing is the way it speaks silently. There is thus a way of letting what is to be said speaks for itself. It consists precisely in renouncing to pronounce the name of what therefore is left free to name itself. Pronouncing the name of something is already somehow including this thing within the law of speaking that defines a thing through its name, intending to grasp the meaning of what is designated with this name. It forces through the name the addressed to obey to the signification that this name points to. The inner law of the linguistic sign has already included the addressed within the institution of language and thus forced it under the authority of the law. Nizami's shift in his understanding of poetry intended to undermine this fatality of language that contaminates poetry. The poet celebrating the rose is already submitting this rose to the law of his art and takes over it so that the rose of no-one becomes his own rose, thus deluding himself. He has thus to find some way to subvert language within poetry by shifting the essence of poetry. A speaking poetry cannot escape the logic of authority that deludes any poetical attempt. There is thus a way of addressing that would subvert this logic, a way of addressing that would turn upside down any logic of domination and would allow to merge out of the logic of authority that his the logic of the world. It should be a poetry that would keep speaking in its essential silence. Writing down a name that is kept in silence, a name that we renounce to pronounce, a name of which the pronunciation even is forgotten or simply unknown, like the name of God in Judaism, kept in the mystery of its silent presentation would be keeping the silence out of which the rose of no-one would speak out of itself, or would let its name pour out without precondition and predictability. Keeping search as the eventuality of silence would keep the eventuality of the absolute event that would be revelation. Indeed some of Nizami's verses are difficult to decipher and to understand, as they were almost encrypted, kept in some crypt where they play hide and seek. It is the general condition of poetry that poetry is hard to decipher because it is always encrypted, like Heraclitus saying about physis when he says that "physis likes encrypting itself». Encrypting is the way of poetry that Nizami somehow points to. Writing is as such the encryption of speaking, the renouncement to speaking. This encryption, the silent body of poetry, is the openness that silence provides for the happening of the unknown and unpredictable poem that pours out as a sudden revelation, tearing the mechanical predictability of skill that encloses the future within calculation. Writing covers the deepness of thinking for knowing under the infinite accumulation of traces that stand on the surface and constitute the despised superficiality of the poem when compared with the serious deepness of the concept. The quality of the poem consists in its happening as a simple surface, as simple covering, as the simple superficiality of the skin. But eventually the skin, the superficiality, the surface of the page is the encryption of the eventual revelation to come and therefore is the most difficult enigma to stand with and for. The superficiality or the simplicity is itself the encryption. The image of something is not its visibility but its encryption. The image is not showing, it is hiding what might come to happen. This eventuality is precisely what is encrypted, or what is traced on the surface of the written page. The written traces are nothing deep. They don't stand as something standing in being, as a being that requires the dimensions of some statue. It is there on the page though it cannot be designated as being. It is there not being like some spec- 
ter that haunts reality from its being a mere surface, or rather a mere scar over a surface. They cannot be denied, though they can always be destroyed, erased or burnt with the page that they break with their lines and curves. They cannot be denied but also they can always be despised and forgotten as not being real. The silent speaking of the poet echoes the non-being present of the traces. Poetry consists not first in its being uttered or pronounced, but in its being written and therefore open to the event of any eventual pronunciation to come. Poetry shows the antecedence of any writing over speaking. Speaking happens only out of a reading, like in the way Muslim tradition records the first revelation of Muhammad. The written book precedes its pronunciation and thus speaking is always the event happening out of the openness of the silent written page.

The essence of poetry that shifts from being a production technique must therefore be sought in the experience of writing. Nizami mentions this experience in these verses I chose :

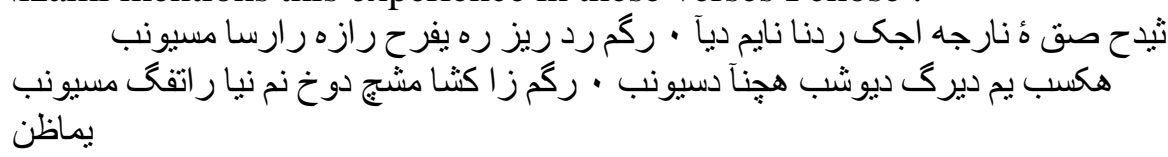

If the poet is the latest remain of the poem, the latest witness of the event of poetry, the written traces are the shade of the silence in which the rose's speaking is reserved for its instant becoming. The question about knowing where is the speaking poet shifts to the a question about knowing where happens the narrative of exile, or rather the narrative of the experienced exile. What would be experiencing exile if the exiled is still somewhere to be found? If the exile is still somewhere the exiled is still necessarily somewhere and thus preserved by exile itself from the experience of the exile. A radical exile would be to disappear from the exile itself. It would require experiencing the desperation of the witness of the exile, or of the one who is experiencing this exile. Exile should be this event, radically new, the Hadith that is the absoluteness of both the single new event and the utterance of poetry. The poem would be both the event and the witnessing of exile. The exile of the exile, or the exiled exiling happens merely as the poem. The poem is the only absolute event, the instant of exiling, because the poet is nowhere to be found in it, because it always already expelled the poet from the poem that he never says and never owns. He is even pushed to the end of the poem, as its anticipated remaining score. The poem unrolls itself so that the poet comes at the end leaving the poem in his own past unfolding until the last word which is the left signature that closes the poem. The signature of the poet is the race of the death of the poem it concludes and therefore witnesses from his own death the dead body of a poem he hasn't pronounced, a poem he has already always failed to pronounce. The poet is thus exiled from speaking in the most radical way standing on the edge, at the point of agony, which is the last letter of the last word as he Nizami - states in this verse.

The exiling exile is the experience of writing. It is the exile of speaking in writing in which speaking disappears in the letters of which the last is the signature of the dead witnessing the poem that already passed away. This absolute exile leaves no standing point, no stop and no rest. It is not a station, maqam, as it would be claimed in the spiritual experience of Sufism. The poet is precisely without any maqam. He is exiled of the possibility of a maqam as well as he is deprived of the possibility of bringing the melancholy of exile to knowledge. He is nowhere from where he could speak and simply announce the bitterness of his exile. He is radically exiled from exile itself. The experience of this exiled exiling is writing. It is in the guise, in the curves and points, of a letter that the poet happens as the dead-end of the poem, which is the openness to the rose's poem. The poet is the body of the letter, the body of the last letter and thus the last and the least body of the poem. But if the poet is this letter he is all the letters as well. All the letters of the poem are the last ones. But it is still necessary to tell how we shall hear, or read, this poetic letter. It is when writing that the poet experiences this absolute exile. Writing however doesn't consist in tracing or carving letters. The same verse stated : "I write a thousand secrets beneath each single letter". Writing is the inscription of an infinity of meanings, of a palimpsest of meanings under each letter. Somehow also 
the singularity of each letter by which it is precisely a letter is established by the infinity of meanings over which it stands as a kind of seal, like the seal over the world at the beginning of the Fusus al-Hikam of ibn 'Arabi. The letter is the trace visible because it stands over the infinite layers of meanings that are therefore its foundation. The letter stands like an enigmatic trace left, abandoned or pushed above and ahead by this strange writing that doesn't write a letter but writes meanings. The letter happens to the inscription of meanings. We would write a letter, a word, a sentence so as to lead to grasping meanings. The meaning should be the result of the written words. But Nizami doesn't write letters nor words. He writes meanings on which comes floating the letter that seals them hiding them, maybe also simulating those meanings, at least preserving them underneath and keeping them secret. What is written is not the expression of a meaning but the meaning that remains hidden. Just writing consists in inscribing secrets, meanings of which the essence consists precisely in their being secret, not secrets that wait to be unveiled, as expected in knowledge, be it metaphysical or mystical, but secrets that don't fall from their secrecy. Writing consists not in unveiling a truth from its veil that keeps it secret but in unveiling the secrets as secrets. It is not switching knowledge to ignorance. The affair of the poet consists not in teaching, spreading knowledge, abolishing ignorance. The affair of the poet is to multiply secrecy through the inscription of secrets sealed by the letters they support. The poet intensifies and worsen secrecy. Bringing knowledge or information consists in seizing and bringing the thing to be known to the area of knowledge, to the domain where it is installed under the light of the intelligence that seeks to know this thing. It consists to expel a thing from its thingness to bring it to its objectity. Objectifying is the process of knowledge and it requires the domination of a domain that is submitted to a dominion. In other terms, knowledge is, since Plato, politics as such. The poet doesn't objectify. He intensifies the secrecy of things. He keeps things in their secrecy. He underlines the secrecy of things and thus reveals the unknowingness of things, the escape of things from all knowledges. He helps things escape from the dominion of knowledge, wether it be philosophical or mystical. If a word is supposed to designate a thing, what would mean that the poet writes an infinity of secrets supporting this word. What are those secrets the secrets of ? If they are the secrets of the thing, then the infinite multiplication of these secrets is the way the poem intensifies the secrecy of things, or rather it is the hiding of things. So poetry obeys thus the essence of nature as Heraclitus had stated. Poetry is encrypting things and therefore stealing the world from any ownership. The world of secrecy, the hiddenness of the world is the removing of any ownership, of any property. The world cannot be appropriated by a proper noun as well as a proper noun cannot be the owner of a poem. The world is exiled from the world we know by the poem that exiles the poet from its exile in poetry itself.

The letters are those strange traces that remain on the surface of this palimpsest of secrets which it seals. They are not written but happen as the scories of the secrets that inscribed. But a secret is precisely what cannot be written. The writing is here again paradoxal. It writes or inscribes what cannot be inscribed. Writing a secret as a secret is impossible as such. Poetry is the writing of the impossible, the writing of the absolute event of exile. The letters, the traces are left on the surface like the poet signature is also left as the end of each inscription. Strictly speaking there is nothing else than those traces. And those traces are what happen through their erasing as says the second verse quoted above. Nizami erases what he writes with his tears. He weeps so much that his tears erase his writing. But indeed he writes nothing if by writing we understand tracing letters on a paper, since he writes secrets that leave letters floating on the page. Thus, the tears are the way this strange encrypting or hiding writing happens. He can't help weeping, but this automaticity of weeping is precisely what constitutes the strangeness of this writing. Writing itself that should be an uncovering and a publicizing is exiled from itself. Weeping produces a shift within writing. As much as the essence of poetry shifts in the experience of silence that much writing shifts in the weeping of exile. His tears wipe out what he writes and at the same time his tears are precisely the ink with which he writes. The tears are both erasing and writing. The erasing of writing is the writing itself, like renouncing saying the poem is poetizing. Bringing poetizing to silence happens in 
the experience of writing out erasing. Or rather writing secrets which includes writing erasing that is itself the experience of exile of self-erasement. It is performing self-erasing, or self-annihilation. The infinity of secrets which are the intensification of the poet self-dissimulation constitute the silent body of the poet's exile from himself.

The writing doesn't bring to being something out of nothingness. It is not creative. It doesn't shift some essence from its possibility to its actuality. It leaves the openness to some traces to happen out of a negation, erasing. It is out of destruction that happens to poetry and not out of nothingness. It doesn't obey to a logic of creation or production. It doesn't submit to an theological and ontological scheme of technical production. This is why also Nizami can say :

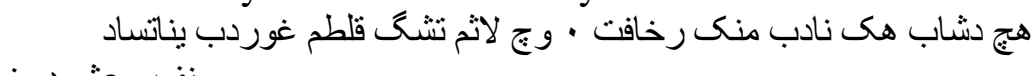

Nizami cannot take pride from his poetical skill since his poetry doesn't obey any skill. The poem happens to the poet who is exiled from himself by being expelled from poetry. His skill is his talent. Poetry doesn't obey the technical schemes of production though the poet is indeed a writer. And it is since he can be understood as a writer that the essence of poetry shifts from art to experience, i.e. enduring annihilation, standing in self-erasing, weeping. Poetry doesn't obey the ontotheological scheme of being. Further on, it undermines it through this strange experience of encrypting writing which happens out of erasing. Moreover, it doesn't erase so as to be able to write anew, like it would be in a palimpsest. The erasing itself is the encryption, the erasing is the writing as such. The happening is the erasing and, therefore, it is the instant substitution. The experience is the experience of the permanent instant substitution, or annihilation. Thus, the negativity of erasing is the performing of negation that opens any happening. Nothing happens out of a previous destruction. It is impossible to separate destruction and creation, erasing and writing, annihilating and bringing to being. It is impossible to separate being from non-being as it is required for giving a ground to any knowledge, a requirement that induces the necessity of a metaphysical foundation for any knowledge. The experience of poetry is the experience of the impossibility of separating annihilation from happening though the unity of both. What poetry displays is that destruction is the happening, erasing is writing, weeping, which is the expression of powerlessness, is power as such.

The written poem is the exposing of any speach, the opening of the voice where happens the event, or rather the opening of the event of the voice. The voice of the rose is always what happens out of control, out of law, with the radical violence of the irruption of the interruption. The written poem gives voice to any eventuality, gives voice to the opening of visibility, opens the scene where the voice tears into pieces any expectation, like the theater play happens out of the text lying in its encryption. The eventuality of voicing, at the most vocifering, stands in writing, in the secrets writing that in its secrecy removes the constraint of possibility. Where possibility always requires the institution of a power so as to bring possibility to its actuality, the secrecy of writing, the encrypting turns down possibility freeing the eventuality of the voice. The voice is the happening spurring each time unexpectedly and unpredictably out of the infinite layers of the secrecy of writing. The voice is this happening in which each time fate is decided towards the fateless silent one, the poet. But the poet is anyone keeping silence, enduring his own silence, anyone who endures the fatelessness of silence, the undetermination of the essence out of which springs the tragic voice that spreads the letters of the poem like a heap of ashes. Against the technology of creation and production that supposes an industrious engineer wholes or survives a grammatic of writing which exposes the mystery of the incoming voices of the silent writing. These voices are always new and though they are never the same, they can never happen out of the certitude of their accordance with any expectation. Unexpectation, unpredictability, impossibility constitute the essences of the voices that on the world-scenery decide about the body of the written secrets. This is why it is commonly said that knowledge comes after the known, or rather that acknowledging or witnessing always follows the traces left of the witnessed that trespassed and passed away. The traces of the letters are 
the testimony or even the oath left on the surface of the pages right when weeping makes them glitter while wiping them away. It is the justice of the poem that he brings witness to its treasured secrecy with the traces that abandons the powerless and fateless melancholy of the signing poet. This powerlessness is experienced at the same time through some kind of confessing despair on one hand and meaninglessness of writing on the other. Thus, Nizâmî tells himself :

$$
\text { دراد و ناز انابز ددركب · هج تتشون زا يو دياً هج دسر ينامجرتب هن }
$$

The strange guise of poetry annihilates the possibility of writing as well the possibility of translating any experience. The poetic experience stands on the edge of the self-destruction of poetry. Poetry happens right at this limit where poetry is impossible, where writing or translating, where expressing itself becomes useless, absurd. Poetry happens where it becomes nonsense. Double limit, cross-limit joining together the opposites: meaning-nonsense and possibilityimpossibility. Poetry is the name of what happens on this limit, of the nonsense that affects the poetical expression of meaning, of the impossibility that strikes its impossibility. At the cross-roads the poet experiences the despair of this limit. Whenever he writes he experiences the nonsense of any poetical expression, or rather he expresses what poetry does to any expression, how poetry affects any expression with nonsense and brings its possible meaning to the essential impossibility belonging to secrecy. The poem says nothing and has nothing to say when it says something. It can always, like in myth, pronounce a wise sentence - and it is tempted to as well as the reader wishes to read it so - but as soon as it speaks wisely it neutralises this wisdom and pushes it to the limit of nonsense. Poetry doesn't only subvert the common order of language as it is commonly said, it brings any language that is supposed to mean something, and thus the linguistic sign as such that is supposed tying together a signifying and a signified, to nonsense, destroying any sign. Poetry destroys signification and writes only secrets. The significations that carry the tracing letters are but the unexpected foam that poetry leaves on its edge while destroying it in the silence of its secrecy. The affair of poetry is nonsense and not meaningfulness, madness and not wisdom. The wisdom of poetry is precisely the destruction of wisdom out of which the letter appears outside poetry, as the traces at the end of which the poet leaves the last letter of his signature. It is not that the poet plans to destroy meaning. It is that the experience of poetry is the experience of the limit of language and expression where language falls fatally into nonsense, where the objectivity of the speech and of the signing author falls into the radical subjectivity of the writing in which there is nothing except the idiomatic mad silence of the author condemned to endure his inner exile from both himself and language. This is why Nizami can also say:

$$
\text { هج نخس دوب هك مفلا نخسب رس مدماً نم · همه هزره يم رد مياً وج رد يآ يناور اك Indeed whatever he }
$$

starts to say he experiences the strangeness of language which condemns him as soon as he starts to speak to speak nonsense. Poetry performs this strange exiling automatic power of language that finally subverts the common confidence in the meaningfulness of language and teaches the rules of speaking so as to master the production of meaning. Poetry is the experience that whenever we speak, even with the highest wisdom, we ultimately speak nonsense we always speak nonsense, right when we intend and speak meaningfully. As much as we want to say something, as much as we want to speak the truth the political machine within language, the poetical voice-recorder automatically writes in the silence of its grave the nonsense of our speech. Like in Greek tragedy we can as much as we want give a meaning to what happens and we can indefinitely entertain disputing about the meaning of our lives, it is always ultimately annihilated by the secret fate that strikes us at these core of our lives. No creed, no belief, no faith, no truth can be given credit so as to decipher the question about what we is existing. Poetry undermines ironically any attempt to give credit to any so called truth. It undermines the institution of truth itself, to the despair of the poet. Poetry is not a project and a domain of the development of culture which could enroll professional poets for the sake of culture. Poetry is not an aim neither a way of life. Poetry is a fatality. It is the irony 
affecting language as such, the fatality of this irony that destroys the language that is precisely the element of the poet, the very existence of the poet.

This irony throws the poet into despair experiencing his own owerlessness until he experiences death, or rather the despairing agony of death, as he confesses 8 :

يهك ز انانج يفيعض يفِب نانج مجنرب · هك تسدب و اب مريمب ز بيهن يناوتان It is confession of the poetical agony, the lack of power, the fatelessness of the poet standing in the silence of writing where he waits for the last letter of the last word to encrypt the

fate of his signature. It is the despair and powerlessness of the poet who signs the nonsense that poetry experiences on the limit, at the cross-roads between the secrets and its voices, between the impossibility or nonsense and meaning, between madness and wisdom, between death and life.

Keywords: poetry, Nizami Ganjavi, ’Divan”, silent witness, essence, signature, skill.

\section{References}

Sa’id Nafisi, Ahwal wa athar-e Qasa'id wa Ghazaliyyat-e Nizami-e Ganjawi, Tehran, 1337, p. 309.

Sa'id Nafisi, Ahwl wa athar-e Qasa'id wa Ghazaliyyat-e Nizami-e Ganjawi, Tehran, 1337, p. 240 .

Göndərilib: 28.04.21

Qəbul edilib: 02.06.21 